\title{
A 2015-ben és 2016-ban vastag- és végbélmútéten átesett daganatos betegek adatainak vizsgálata matematikai-statisztikai modellel
}

\author{
Benedek Zsófia dr. \\ Semmelweis Egyetem, Általános Orvostudományi Kar, Mentális Egészségtudományok Doktori Iskola, Budapest
}

Bevezetés: A 2015-ben és 2016-ban colorectalis rosszindulatú daganatok miatt laparoszkópos és hagyományos beavatkozásokon átesett betegek országos adatait vizsgáltuk meg.

Célkitüzés: Magyarországon 2015-ben és 2016-ban a rosszindulatú vastag- és végbéldaganatos megbetegedések miatt tervezetten elvégzett colorectalis mútétek adatainak kapcsolatait vizsgáltuk ápolást indokló, kísérő és szövődmény-diagnóziscsoportok, beavatkozási helyszínek, valamint a betegek kora és neme között.

Módszer: A kapcsolatokat kereszttáblás elemzésekkel és a parciális legkisebb négyzetek módszerére épülő strukturális egyenletek modelljével vizsgáltuk meg. Három strukturális modell (nyitott, laparoszkópos mútétes és teljes vizsgálati populációcsoportok) eredményét hasonlítottuk össze.

Eredmények: 4941 esetet vizsgáltunk; a nyitott colorectalis mútétes csoportba 4562, míg a laparoszkópos csoportba 379 eset került. A modellek alapján a laparoszkópos mútéteknél összefüggés van az intézetek progresszivitási szintje és a szövődmény- és kísérőbetegség-csoportokkal. A háttértényezők minden esetben pozitív irányú hatást fejtenek ki a kísérő betegségekre. A blokkokon belül a szövődmények közül a laparoszkópos mútétek esetében a vérzés, anaemia, a teljes populációs és nyitott modellben a szeptikus szövődmények szerepe a meghatározó.

Következtetés: Adataink alapján a magasabb progresszivitású ellátóhelyeken végzett laparoszkópos mútéteknél a multimorbid betegek kerülnek ellátásra. A laparoszkópos csoportnál minél magasabb progresszivitású helyeken operálják a betegeket, annál kevésbé domináns a szövődmények kódolása, azaz vagy kevesebb a szövődmény, vagy a többi ellátóhoz képest máshogy kódolják azokat. A strukturális modellértékek eltérésének okai között a betegek műtéti szelekcióját feltételezzük, de ennek pontos feltérképezése céljából további kutatások szükségesek. A szövődmények közül a nyitott és teljes vizsgálati csoportra jellemző a szepszis, a hashártyagyulladás és a béltályog faktorok meghatározó szerepe, szemben a laparoszkópos modell szövődményeire, ahol a vérzés, anaemia domináns, ami a betegek szelekciója mellett a mútéttechnikai eltérésekkel függ össze.

Orv Hetil. 2019; 160(11): 426-434.

Kulcsszavak: colorectalis, daganat, sebészet, betegadat-elemzés

\section{Analysis of patients with colorectal cancer treated with surgery in 2015 and 2016, using a statistical model}

Introduction: The purpose of this study was to analyze the data of the open and laparoscopic colorectal cancer surgeries countrywide in an administrative database of the National Health Insurance Fund of Hungary in 2015-2016. Aim: Hungarian surgical data of colorectal cancer from 2015-2016 were analyzed based on the following objectives: diagnosis of care, complications and co-morbidities; age; sex and medical institutions.

Method: We used crosstabs and partial least squares path modeling to analyze the relations between data groups. Results of three LVPLS models (group of open, laparoscopic interventions and the whole population of the survey) were compared.

Results: From the 4941 analyzed operative cases, 4562 were open and 379 laparoscopic. Based on the three LVPLS models, we found nexus between complication groups and co-morbidity groups and progressivity of medical institutions in laparoscopic operations. As far as complications, in the laparoscopic model bleeding and anaemia, in cases of total population and open operations septic complications played dominant role. 
Conclusions: Laparoscopic resections in patients with multiple co-morbidities are carried out in medical institutions with high professional progressivity most frequently. In cases of laparoscopic colorectal operations, the higher the progressivity of an institution, the lower the complication rate was. Differences in the results in the models may be due to patient selection, and further research should be carried out in this regard. Anaemia and bleeding are dominant complication factors in the laparoscopic model, which are influenced by patient selection besides the differenced in surgical technique.

Keywords: colorectal, cancer, surgery, patient data analysis

Benedek Zs. [Analysis of patients with colorectal cancer treated with surgery in 2015-2016, using a statistical model]. Orv Hetil. 2019; 160(11): 426-434.

(Beérkezett: 2018. szeptember 10.; elfogadva: 2018. október 19.)

\begin{abstract}
Rövidítések
$\mathrm{A}_{\mathrm{B}}=$ aszkriptív háttértényező, háttérváltozó, ez esetben a biológiai hátteret: biológiai nemet és kort jelenti; $A_{\mathrm{B}}=$ ápolást indokló fódiagnózis; ÁEEK = Állami Egészségügyi Ellátó Központ; $\mathrm{BNO}=$ betegségek nemzetközi osztályozására szolgáló kódrendszer; COPD = (chronic obstructive pulmonary disease) idült obstuktív tüdőbetegség; $\mathrm{E}_{\mathrm{i}}=$ ellátóintézet; $\mathrm{EMMI}=$ Emberi Erőforrások Minisztériuma; $\mathrm{K}_{\mathrm{B}}=$ kísérőbetegségek; $\mathrm{LCR}$ = laparoszkópos colorectalis reszekció; LVPLS = (latent variables path analysis with partial least squares estimation) latens változós útelemzés parciális legkisebb négyzetes becsléssel, amely más néven mint PLS-SEM (partial least squares structural equation modeling $=$ a parciális legkisebb négyzetek módszerére épülő strukturális egyenletek modellje) is szokott szerepelni a közleményekben; NEAK = Nemzeti Egészségbiztosítási Alapkezelő (korábban OEP = Országos Egészségbiztosítási Pénztár $)$; OCR $=($ open colon resection $)$ nyitott colorectalis reszekció; $\mathrm{SZ}=$ szövődmény; $\mathrm{TP}=$ teljes vizsgálati populáció
\end{abstract}

A laparoszkópos vastag- és végbélsebészet a nemzetközi szakirodalom által széles körüen igazoltan jobb élettani (gyorsabb a bélmotilitás helyreállása, kisebb fájdalomérzet, gyors mobilizálhatóság) és rövid távú hatásokkal (kevesebb seb és varratelégtelenség, kisebb posztoperatív sérv-előfordulási gyakoriság, rövidebb kórházi ápolási időszak) [1-6] járó beavatkozásokat foglal magába a nyitott colorectalis mütétekhez képest. A technikailag eltérő nyitott- (nagy hasi metszésből végzett) és laparoszkópos mútéti típusoknál a hosszú távú kimenetelt vizsgálva az onkológiai kimenetelben számos kutatás nem ír le szignifikáns eltérést [7-11]. A nyitott műtétekhez képest a laparoszkópos mútétek további jellemzője az alacsonyabb kórházi halálozási [12] és alacsonyabb szövődményráta [7, 9, 13-15]. Magyarországon a laparoszkópos colorectalis sebészet az ezredforduló óta van jelen [16]. Napjainkra a modern eljárások országszerte elterjedtek, és a mindennapos mútétek között végzik őket a sebészeti osztályokon. 2014 előtt a laparoszkópos colorectalis beavatkozások (LCR) adatait nem adminisztrálták központilag, a nyitott colorectalis mütétek (OCR) kódjait használták a laparoszkópos megfelelőik kódolására is
[17]. Az adminisztráció hiánya miatt nincs egyértelmú adat a 2014 előtt elvégzett LCR-mútétekről. A hiányos adminisztráció mellett a 2014 előtti időszakban az egészségbiztosító egyenlő mértékben és módon finanszírozta a hagyományos és a laparoszkópos colorectalis eljárásokat, ami anyagi korlátot jelentett a mütéti szám növelése szempontjából [18], mivel a laparoszkópiához szükséges speciális, nagyobb értékű eszközök nem kerültek külön vagy tételes finanszírozásra. 2014 februárjától a 4/2014. (I. 20.) EMMI rendelet eredményeképpen a laparoszkópos colorectalis mútétek egyedi beavatkozási kódokat kaptak, és a beavatkozáshoz szükséges egyszer használatos mûszerek finanszírozottá váltak. Az LCR-technika terjedése ennek ellenére lassúnak mondható Magyarországon, mert a nemzetközi irodalomban [19] publikált tanulási folyamat (learning curve, 88-152 eset operálása) [20-22] befejezése az alacsony mútéti esetszámok miatt lassabb, ezzel befolyásolva a rövid távú eredményeket is. $\mathrm{Az}$ adatok transzparenciája nőtt ugyan, de továbbra sem nevezhető jól vizsgálhatónak az egészségbiztosító adatbázisa, mert a reoperációk számát nem lehet pontosan meghatározni, mivel a primer mütétekkel azonos naptári napon rögzített reoperációk nem különülnek el a primer mútéti eseménytől, hanem annak részkódjaként jelenhetnek meg, és az LCR-esetekben a konverziókat sem lehet megfelelóen kódolni.

Jelen kutatásunk rendhagyó, mert egy, a társadalomtudományi kutatásokban rendszeresen alkalmazott másodgenerációs statisztikai módszert használtunk méréseinkhez. A strukturális egyenletek modelljei közül a latens változós útelemzést alkalmaztuk parciális legkisebb négyzetes becsléssel (LVPLS), amely elsősorban egy exploratív modell, amely a függő változók varianciáit próbálja a lehető legjobban magyarázni, reprodukálni [23]. A felhasznált statisztikai módszer (LVPLS) alkalmazása sok változó szimultán elemzését teszi lehetővé, amellyel a különböző változók egymáshoz való kapcsolatát térképezzük fel, így információt kapunk a mútétek, a kódolt diagnózisok, a helyszínek és a beteg háttértényezői (életkor és nem) közötti összefüggésekről. A latens változós útelemzés segítségével megvizsgáljuk, hogy milyen közvetlen és közvetett hatások befolyásolják a modelleket. 
Ezek a változók mért manifeszt változók, amelyek a jelen esetben mútétek, diagnózisok, helyszínek és betegek jellemzőinek a mérési adatai. A manifeszt változóblokkok mögött latens változók vannak, amelyek az egyes változóblokkok, területek közötti strukturális kapcsolatokra (standardizált regressziós együtthatókra) - és a latens változók és a manifeszt (mért) változók faktorsúlyaira adnak becslést.

\section{Célkitűzés}

Kutatásunkban a Magyarországon rosszindulatú vastagés végbéldaganatos megbetegedés miatt tervezetten végzett laparoszkópos és nyitott colorectalis mútétek kapcsolatait vizsgáljuk LVPLS-technikával a mütétet indokló, a kísérő és a szövődmény-betegségcsoportok, a beavatkozási helyszínek, a betegek kora és biológiai neme között.

\section{Módszer}

Adatforrásként az Állami Egészségügyi Ellátó Központ (ÁEEK) betegforgalmi adatait használtuk. ${ }^{1} \mathrm{Az}$ adatokat a nemzeti egészségbiztosító adatbázisából kutatási céllal az ÁEEK igényelte. A kutatás alap elemei műtétiesemény-szintűek. Esemény- és betegszinten duplikátumszưrést végeztünk, ezért nem fordul elő a felhasznált adatbázisban adatduplikáció. Az aktív fekvőbeteg-jelentésekből származó, primer tervezett mütéteken átesett betegek adatai hasonló kutatásokkal megegyezően [24] egyedi azonosításra alkalmatlan betegazonosítókkal vannak ellátva, ezek biztosítják az ellátási események összekapcsolási lehetőségét. A vizsgált beavatkozásokat a mütéti kódok (1. táblázat) alapján gyưjtöttük össze. Az érintett betegek rekordjait, az ellátóosztály azonosítóját, az adott ellátáshoz kapcsolódó diagnózisokat (BNO), valamint a betegek nemét és életkorát a leválogatott beavatkozási kódokhoz kapcsoltuk. A lekérés és adatkapcsolás módszertanát az 1 .ábrán szemléltetjük.

A diagnózisokat kódolási típus szerint ápolást (és mütétet) indokló, kísérő és szövődménydiagnózis (3. BNO, 4. BNO, 5. BNO) szerint csoportosítottuk, a NEAKadatbázis mintájában a 15 leggyakoribb kórkép kódjait gyưjtő csoportokba soroltuk. Mivel célunk az volt, hogy felderítsük a változóink kapcsolatrendszerét, és megpróbáljuk a sok változót redukálni a kapcsolatrendszert legjobban reprodukáló faktorokkal, a kijelölt szövődménydiagnózisok közül a sebészeti okra visszavezethető vagy a sebészeti ellátást igénylő szövődményeket emeltük a vizsgálatunkba, míg a kísérő betegségek közül azokat, amelyek modellalkotó kísérleteink alapján szignifikáns hatást gyakoroltak a modell egyensúlyára. Az informá-

\footnotetext{
${ }^{1}$ Az ÁEEK/000810-001/2017-es együttmúködési megállapodás alapján tör tént az adatkérés az ÁEEK adatbázisából, amely a NEAK-tól (korábbi OEP) származó adatokat rendszerezte.
}

1. táblázat |A vizsgált diagnóziscsoportok kódja és megnevezései

\begin{tabular}{|c|c|c|}
\hline $\begin{array}{l}\text { Ápolást indokló } \\
\text { diagnózisok } \\
\text { megnevezése és } \\
\text { BNO-kódjai }\end{array}$ & $\begin{array}{l}\text { Szövődménydiagnózi- } \\
\text { sok megnevezése és } \\
\text { BNO-kódjai }\end{array}$ & $\begin{array}{l}\text { Kísérő diagnózisok } \\
\text { megnevezése és } \\
\text { BNO-kódjai }\end{array}$ \\
\hline $\begin{array}{l}\text { Vastagbél rosszindu- } \\
\text { latú daganata } \\
\left(\mathrm{C} 18^{* *}-\mathrm{C} 19^{* *}\right)\end{array}$ & $\begin{array}{l}\text { Béltályog, } \\
\text { bélátfúródás }\left(\mathrm{K} 63^{* *}\right)\end{array}$ & $\begin{array}{l}\text { Máj másodlagos } \\
\text { rosszindulatú } \\
\text { daganata }(\mathrm{C} 7870)\end{array}$ \\
\hline \multirow[t]{8}{*}{$\begin{array}{l}\text { Végbél rosszindulatú } \\
\text { daganata }(\mathrm{C} 20 \mathrm{H} 0)\end{array}$} & $\begin{array}{l}\text { Hashártyagyulladás } \\
\left(\mathrm{K}^{*} 5^{* *}\right)\end{array}$ & $\begin{array}{l}\text { Magas vérnyomás } \\
\text { (I10H0) }\end{array}$ \\
\hline & $\begin{array}{l}\text { Szöveti gyulladás, } \\
\text { tályog, fekély } \\
\left(\mathrm{L} 02^{* *}-\mathrm{L} 89^{* *}\right)\end{array}$ & $\begin{array}{l}\text { ISZB és hipertenzív } \\
\text { szívbetegség } \\
\left(\mathrm{I} 11^{* *}-\mathrm{I} 24^{* *}-\right. \\
\left.\mathrm{I} 25^{* *}\right)\end{array}$ \\
\hline & $\begin{array}{l}\text { Vérzés és anaemia } \\
\left(\mathrm{D} 62^{* *}-\mathrm{D} 64^{* *}\right)\end{array}$ & $\begin{array}{l}\text { Hashártya-összenö- } \\
\text { vések }\left(\mathrm{K} 66^{* *}\right)\end{array}$ \\
\hline & $\begin{array}{l}\text { Bélelzáródás, } \\
\text { volvulus }\left(K 56^{* *}\right)\end{array}$ & $\operatorname{COPD}\left(\mathrm{J} 44^{* *}\right)$ \\
\hline & $\begin{array}{l}\text { Beavatkozás során } \\
\text { létrejött szövődmény } \\
\text { (kifejezetten sebészi) } \\
\left(\mathrm{T} 81^{* *}\right)\end{array}$ & $\begin{array}{l}\text { Pitvarfibrilláció } \\
\left(\mathrm{I} 48^{* *}\right)\end{array}$ \\
\hline & $\begin{array}{l}\text { Septicaemia } \\
\left(\mathrm{A} 40^{* *}-\mathrm{A} 41^{* *}\right)\end{array}$ & $\begin{array}{l}\text { Diabetes összes } \\
\text { megjelenése }\left(\mathrm{E} 11^{* *}\right)\end{array}$ \\
\hline & & $\begin{array}{l}\text { Atherosclerosis } \\
\left(\mathrm{I} 70^{* *}\right)\end{array}$ \\
\hline & & $\begin{array}{l}\text { Krónikus veseelégte- } \\
\text { lenség }\left(\mathrm{N}_{1} 8^{* *}\right)\end{array}$ \\
\hline
\end{tabular}

*Jelölés: A harmadik és negyedik változó számjegyet jelöli a kódtöredékekben, ezek a számok a különféle diagnózisokat egyértelmúsítik. A jelen kutatásban csoportosított kódokat használtunk, ezért jelöljük * vagy ** jellel a csoportok alcsoportjainak összességét.

BNO = betegségek nemzetközi osztályozása; COPD = idült obstruktív tüdőbetegség; ISZB = ischaemiás szívbetegség

cióveszteség minimalizálása érdekében, a latens változók vizsgálata céljából faktoranalízist alkalmazva alakítottuk ki a végső modellek vizsgált változóit a blokkon belül. Így került sor az 1. táblázatban kiemelt diagnóziscsoportok vizsgálatára.

\section{Statisztikai elemzés}

Kutatásunkban a másodgenerációs latens változós strukturális egyenletek modelljét használtuk, amelynek paramétereit a parciális legkisebb négyzetek módszerével becsültük. Változóinkat úgynevezett „blokkokba” rendeztük. A strukturális modellben úgynevezett útegyütthatókkal (amelyek tulajdonképpen standardizált regressziós együtthatóként értelmezhetők) írjuk le a blokkok közötti kapcsolatokat. A blokkokon belüli kapcsolatokat szintén dimenzió nélküli arányszámokkal írtuk le, ezek a korrelációs együtthatóknak megfelelő faktorok, az egyes változók közötti faktorsúlyok, a lehetséges értékeik -1 és 


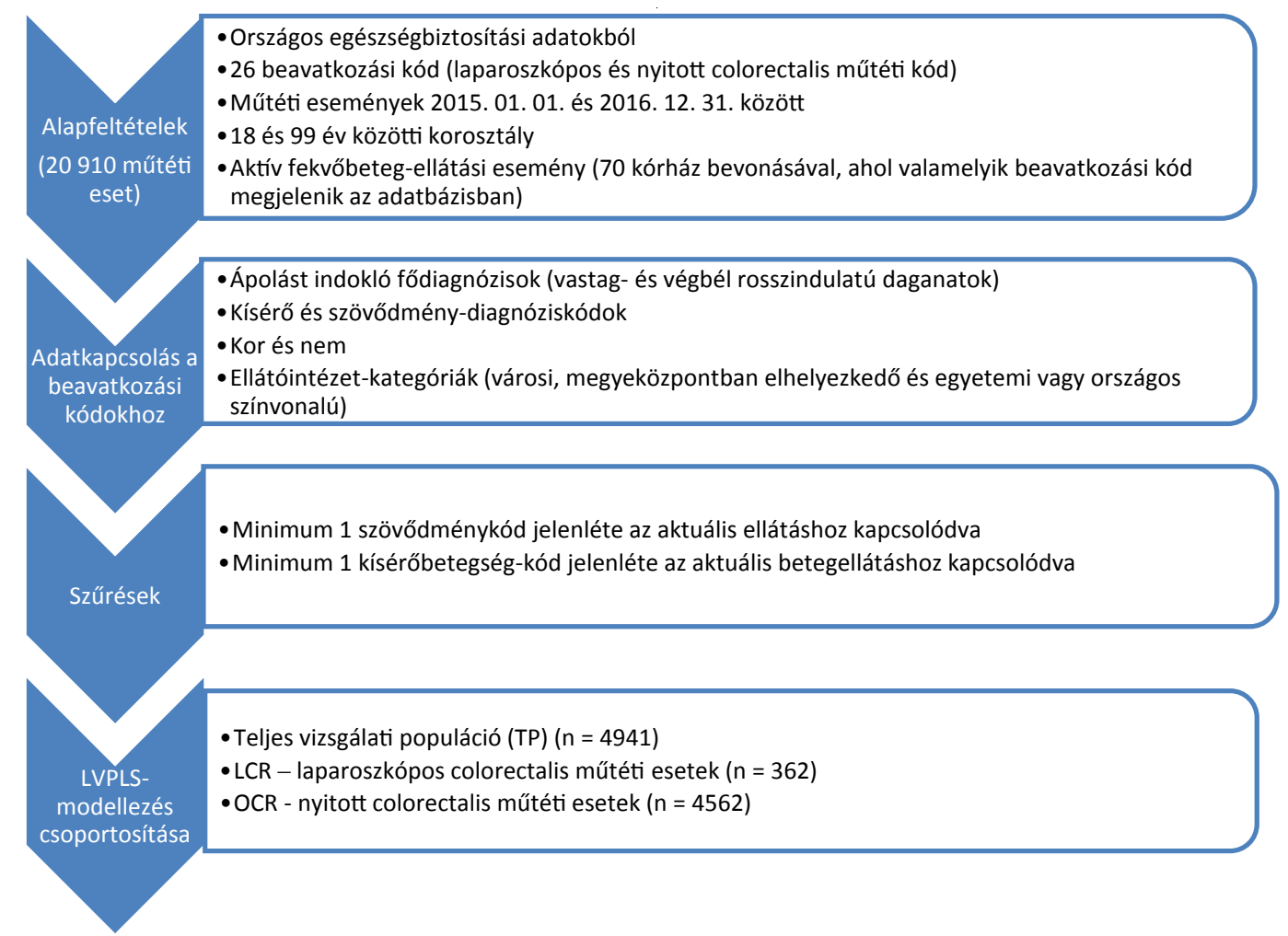

1. ábra

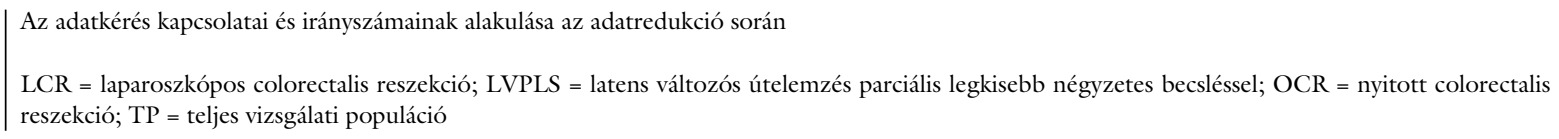

1 közötti intervallumban értelmezhetők. Adatbázisunk adatait három különálló strukturális modellben vizsgáltuk meg és hasonlítottuk össze (2. táblázat). Az első modell kizárólag LCR-, a második modell kizárólag OCR-mútéten átesett betegek adatait, míg a harmadik modell a teljes betegpopulációt (OCR + LCR eseteket egyaránt) tartalmazó adatokat foglalta magában.

A strukturális modelleknek minden esetben öt blokkjuk van; az első kettő az aszkriptív háttérváltozók mintáit tartalmazza, a kort, a nemet és a mútéti helyszín kategorikus változóját, míg a harmadik, a negyedik és az ötödik blokk az ápolást indokló fô, kíséró és szövődmény-diagnóziscsoportokat (2. ábra).

$\mathrm{Az}$ aszkriptív háttérváltozóknak az összes diagnóziscsoporttal van kapcsolatuk. A modell blokkjai közötti kapcsolatokat (például $\mathrm{A}_{\mathrm{B}} \mathrm{K}_{\mathrm{B}}$ ) az útegyütthatók jelenítik meg. A kapcsolatokat jellemző modelleket elméleti megfontolások és az adatok előzetes elemzése alapján szerkesztettük meg. A modell bal oldala, a háttérváltozók mintája azt feltételezi, hogy a betegre jellemző aszkriptív háttértényezőt $\left(A_{B}\right)$ alkotva kapcsolat lesz a kor és a nem között. A bal oldalon további egy - háttérmintázatot alkotó - változó van, az ellátóintézet $\left(\mathrm{E}_{\mathrm{i}}\right)$, amely egy kategorikus változó (kategóriák: városi, megyei központban elhelyezkedő kórházak, országos vagy egyetemi intézetek), értéke a magasabb szakmai színvonalú helyszíneken a kategória skálájának magasabb értékét képviseli. A jobb oldalon elkülönül az ápolást indokló betegségek $\left(\hat{A}_{B}\right)$, a szövődmények $(S Z)$ és a kísérő betegségek $\left(K_{B}\right)$ mintázata (blokkokba rendezve). Az ápolást indokló betegségeket a vastag- és a végbél rosszindulatú daganatai jelentik, ezek alkotják az $\AA_{\mathrm{B}}$-faktort. A szövődményfaktort a klinikailag sebészeti mútéti eseményekhez köthető betegségek faktorsúlyai alkotják. A szövődményfaktorra a kísérő betegségek, az ápolást indokló betegségek, illetve aZ aszkriptív tényezők koefficiensei $\left(\hat{A}_{B} S Z, A_{B} S Z, E_{I} S Z\right.$, $\mathrm{K}_{\mathrm{B}} \mathrm{SZ}$ ) gyakorolhatnak hatást modellünkben. A kíséróbetegség-blokkot a korábban leírt módon csoportosított betegségkódcsoportok alkotják, melyeket az aszkriptív háttérmintázat és az intézményi háttérmintázat befolyásolnak $\left(\mathrm{E}_{\mathrm{I}} \mathrm{K}_{\mathrm{B}}\right.$ és $\left.\mathrm{A}_{\mathrm{B}} \mathrm{K}_{\mathrm{B}}\right)$ koefficiensükkel. Feltételezésünk szerint lehetséges összefüggés az ellátóintézetek típusai és a különböző betegségtípusok között, ezért vizsgáljuk a hatások milyenségét (2. ábra).

$\mathrm{Az}$ útegyütthatók vizsgálata szignifikáns volt az rms $\operatorname{cov}(\mathrm{f}, \mathrm{x})$, a latens faktorok és a külső, manifeszt változók kovarianciái négyzetes középértékének négyzetgyökét vizsgálva, ha $20 \%$-os a manifeszt varianciáknak, különbözőségeknek a magyarázott aránya, akkor statisztikailag a modell magyarázata a „nagyon jó” kategóriába helyezhető be; a jelen kutatásban a mutatók $20 \%$ körüli értéküek (3. táblázat).

Szoftverek: az elemzések során MS Excel, SPSS (24. verzió) adatbázis-elemző és PLS [25] (1.8 verzió) programot alkalmaztunk. 
2. táblázat

Az LCR és az OCR mútéti csoportok vizsgálata korcsoport és nem szerinti eloszlásban

\begin{tabular}{|c|c|c|c|c|c|}
\hline Nemek & Korosztályok & & OCR & LCR & Total \\
\hline \multirow[t]{14}{*}{ Férfiak } & \multirow[t]{2}{*}{$X-39$} & $\begin{array}{l}\text { Esetszám (műtét, } \\
\text { darab) }\end{array}$ & 26 & 1 & 27 \\
\hline & & $\begin{array}{l}\text { \% (összes mütéti } \\
\text { esetszámhoz } \\
\text { képest) }\end{array}$ & $1,1 \%$ & $0,5 \%$ & $1,0 \%$ \\
\hline & \multirow[t]{2}{*}{$40-49$} & $\begin{array}{l}\text { Esetszám (műtét, } \\
\text { darab) }\end{array}$ & 57 & 8 & 65 \\
\hline & & $\begin{array}{l}\text { \% (összes mütéti } \\
\text { esetszámhoz } \\
\text { képest) }\end{array}$ & $2,3 \%$ & $3,8 \%$ & $2,5 \%$ \\
\hline & \multirow[t]{2}{*}{$50-59$} & $\begin{array}{l}\text { Esetszám (mûtét, } \\
\text { darab) }\end{array}$ & 230 & 25 & 255 \\
\hline & & $\begin{array}{l}\text { \% (összes mútéti } \\
\text { esetszámhoz } \\
\text { képest) }\end{array}$ & $9,4 \%$ & $11,9 \%$ & $9,6 \%$ \\
\hline & \multirow[t]{2}{*}{$60-69$} & $\begin{array}{l}\text { Esetszám (mûtét, } \\
\text { darab) }\end{array}$ & 805 & 68 & 873 \\
\hline & & $\begin{array}{l}\text { \% (összes mútéti } \\
\text { esetszámhoz } \\
\text { képest) }\end{array}$ & $33,0 \%$ & $32,4 \%$ & $32,9 \%$ \\
\hline & \multirow[t]{2}{*}{$70-79$} & $\begin{array}{l}\text { Esetszám (mûtét, } \\
\text { darab) }\end{array}$ & 899 & 76 & 975 \\
\hline & & $\begin{array}{l}\text { \% (összes mútéti } \\
\text { esetszámhoz } \\
\text { képest) }\end{array}$ & $36,8 \%$ & $36,2 \%$ & $36,8 \%$ \\
\hline & \multirow[t]{2}{*}{$80-X$} & $\begin{array}{l}\text { Esetszám (műtét, } \\
\text { darab) }\end{array}$ & 425 & 32 & 457 \\
\hline & & $\begin{array}{l}\text { \% (összes mútéti } \\
\text { esetszámhoz } \\
\text { képest) }\end{array}$ & $17,4 \%$ & $15,2 \%$ & $17,2 \%$ \\
\hline & \multirow[t]{2}{*}{$\begin{array}{l}\text { Férfiak } \\
\text { összesen }\end{array}$} & $\begin{array}{l}\text { Esetszám (mütét, } \\
\text { darab) }\end{array}$ & 2442 & 210 & 2652 \\
\hline & & & $100,0 \%$ & $100,0 \%$ & $100,0 \%$ \\
\hline \multirow[t]{6}{*}{ Nők } & \multirow[t]{2}{*}{$\mathrm{X}-39$} & $\begin{array}{l}\text { Esetszám (mûtét, } \\
\text { darab) }\end{array}$ & 13 & 1 & 14 \\
\hline & & $\begin{array}{l}\text { \% (összes mütéti } \\
\text { esetszámhoz } \\
\text { képest) }\end{array}$ & $0,6 \%$ & $0,6 \%$ & $0,6 \%$ \\
\hline & \multirow[t]{2}{*}{$40-49$} & $\begin{array}{l}\text { Esetszám (mûtét, } \\
\text { darab) }\end{array}$ & 48 & 7 & 55 \\
\hline & & $\begin{array}{l}\text { \% (összes mútéti } \\
\text { esetszámhoz } \\
\text { képest) }\end{array}$ & $2,3 \%$ & $4,1 \%$ & $2,4 \%$ \\
\hline & \multirow[t]{2}{*}{$50-59$} & $\begin{array}{l}\text { Esetszám (műtét, } \\
\text { darab) }\end{array}$ & 219 & 13 & 232 \\
\hline & & $\begin{array}{l}\text { \% (összes mútéti } \\
\text { esetszámhoz } \\
\text { képest) }\end{array}$ & $10,3 \%$ & $7,7 \%$ & $10,1 \%$ \\
\hline
\end{tabular}

\section{Eredmények}

Vizsgálatunk során a bevonási és kizárási kritériumoknak az eredeti 20 910, a NEAK-adatbázisból kapott elemi egységből 4941 eset felelt meg, ezt a 4941 esetet a to-

\begin{tabular}{|c|c|c|c|c|c|}
\hline Nemek & Korosztályok & & OCR & LCR & Total \\
\hline & \multirow[t]{2}{*}{$60-69$} & $\begin{array}{l}\text { Esetszám (mútét, } \\
\text { darab) }\end{array}$ & 521 & 45 & 566 \\
\hline & & $\begin{array}{l}\text { \% (összes mútéti } \\
\text { esetszámhoz } \\
\text { képest) }\end{array}$ & $24,6 \%$ & $26,6 \%$ & $24,7 \%$ \\
\hline & \multirow[t]{2}{*}{$70-79$} & $\begin{array}{l}\text { Esetszám (mútét, } \\
\text { darab) }\end{array}$ & 771 & 73 & 844 \\
\hline & & $\begin{array}{l}\text { \% (összes mútéti } \\
\text { esetszámhoz } \\
\text { képest) }\end{array}$ & $36,4 \%$ & $43,2 \%$ & $36,9 \%$ \\
\hline & \multirow[t]{2}{*}{$80-X$} & $\begin{array}{l}\text { Esetszám (mủtét, } \\
\text { darab) }\end{array}$ & 548 & 30 & 578 \\
\hline & & $\begin{array}{l}\text { \% (összes mútéti } \\
\text { esetszámhoz } \\
\text { képest) }\end{array}$ & $25,8 \%$ & $17,8 \%$ & $25,3 \%$ \\
\hline & \multirow[t]{2}{*}{$\begin{array}{l}\text { Nők } \\
\text { összesen }\end{array}$} & $\begin{array}{l}\text { Esetszám (mútét, } \\
\text { darab) }\end{array}$ & 2120 & 169 & 2289 \\
\hline & & & $100,0 \%$ & $100,0 \%$ & $100,0 \%$ \\
\hline \multirow[t]{14}{*}{ Összes } & \multirow[t]{2}{*}{$\mathrm{X}-39$} & $\begin{array}{l}\text { Esetszám (mủtét, } \\
\text { darab) }\end{array}$ & 39 & 2 & 41 \\
\hline & & $\begin{array}{l}\text { \% (összes mútéti } \\
\text { esetszámhoz } \\
\text { képest) }\end{array}$ & $0,9 \%$ & $0,5 \%$ & $0,8 \%$ \\
\hline & \multirow[t]{2}{*}{$40-49$} & $\begin{array}{l}\text { Esetszám (mútét, } \\
\text { darab) }\end{array}$ & 105 & 15 & 120 \\
\hline & & $\begin{array}{l}\text { \% (összes mútéti } \\
\text { esetszámhoz } \\
\text { képest) }\end{array}$ & $2,3 \%$ & $4,0 \%$ & $2,4 \%$ \\
\hline & \multirow[t]{2}{*}{$50-59$} & $\begin{array}{l}\text { Esetszám (mútét, } \\
\text { darab) }\end{array}$ & 449 & 38 & 487 \\
\hline & & $\begin{array}{l}\text { \% (összes mútéti } \\
\text { esetszámhoz } \\
\text { képest) }\end{array}$ & $9,8 \%$ & $10,0 \%$ & $9,9 \%$ \\
\hline & \multirow[t]{2}{*}{$60-69$} & $\begin{array}{l}\text { Esetszám (mútét, } \\
\text { darab) }\end{array}$ & 1326 & 113 & 1439 \\
\hline & & $\begin{array}{l}\text { \% (összes mútéti } \\
\text { esetszámhoz } \\
\text { képest) }\end{array}$ & $29,1 \%$ & $29,8 \%$ & $29,1 \%$ \\
\hline & \multirow[t]{2}{*}{$70-79$} & $\begin{array}{l}\text { Esetszám (mútét, } \\
\text { darab) }\end{array}$ & 1670 & 149 & 1819 \\
\hline & & $\begin{array}{l}\text { \% (összes múttéti } \\
\text { esetszámhoz } \\
\text { képest) }\end{array}$ & $36,6 \%$ & $39,3 \%$ & $36,8 \%$ \\
\hline & \multirow[t]{2}{*}{$80-X$} & $\begin{array}{l}\text { Esetszám (mútét, } \\
\text { darab) }\end{array}$ & 973 & 62 & 1035 \\
\hline & & $\begin{array}{l}\text { \% (összes mútéti } \\
\text { esetszámhoz } \\
\text { képest) }\end{array}$ & $21,3 \%$ & $16,4 \%$ & $20,9 \%$ \\
\hline & \multirow[t]{2}{*}{$\begin{array}{l}\text { Mind- } \\
\text { összesen }\end{array}$} & $\begin{array}{l}\text { Esetszám (mútét, } \\
\text { darab) }\end{array}$ & 4562 & 379 & 4941 \\
\hline & & & 100,0 & $100,0 \%$ & $100,0 \%$ \\
\hline
\end{tabular}

LCR = laparoszkópos colorectalis reszekció; OCR = nyitott colorectalis reszekció

vábbiakban teljes vizsgálati populációként nevezzük meg (TP). Az OCR-csoportba 4562, míg az LCR-be 379 eset került. A 2. táblázatban látható a nyitott és a laparoszkópos mútétek száma és a mútétek részaránya korcsoport és nem szerinti bontásban. A csoportokban 


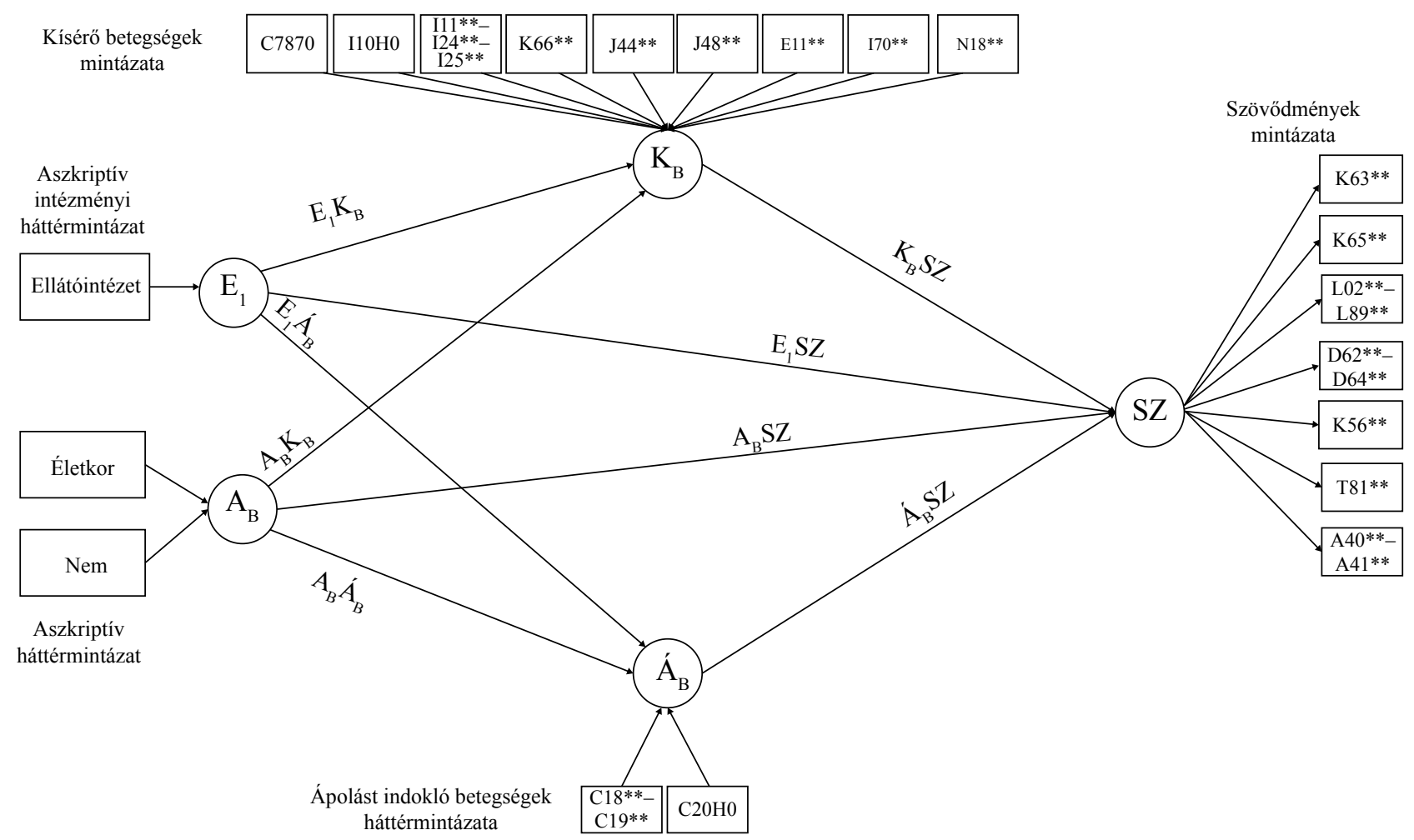

2. ábra $\quad$ A kutatásunk alapját adó LVPLS strukturális modelljének elméleti ábrája. Az ábrán látható betegségcsoportok kódjai megegyeznek az 1. táblázatban található betegségcsoportok BNO-kódjaival

$\mathrm{BNO}=$ betegségek nemzetközi osztályozása; LVPLS = latens változós útelemzés parciális legkisebb négyzetes becsléssel

2289 nő- és 2652 férfi beteg adatai kerültek be, az LCRcsoportba tartozott a férfi betegek 7,9\%-a, míg a nők 7,4\%-a. Khi-négyzet-teszttel vizsgálva a két mútéti típus és a nemek között nem találtunk szignifikáns összefüggést $\mathrm{p}>0,05$ szignifikanciaszinten sem $\left(\mathrm{p}=0,481 ; \chi^{2}(5)\right.$ $=0,497)$. Mivel daganatos betegségeket vizsgáltunk, amelyek fiatalabb korban ritkábban képeznek OCR- vagy LCR-indikációt, a 60 év alatti korosztályban alacsonyabb a mútéti esetszám, az 50-59 éves korosztályban éri el az esetek 10\% körüli értékét. Megfigyelhető, hogy a 60-69 éves korcsoportban az OCR- és LCR-mütétek aránya közel azonos (férfiak esetében 33\% vs. 32,5\% míg nók esetében $24,6 \%$ vs. $26,6 \%$ ) a két mútéti csoporton belül. A khi-négyzet-teszttel szintén nem találtunk szignifikáns összefüggést p>0,05 szignifikanciaszinten a korcsoportok és a mútéti típusok között $\left(\mathrm{p}=0,097 ; \chi^{2}(5)=9,305\right)$, szétbontva nemenként férfiaknál $\mathrm{p}=0,523 ; \chi^{2}(5)=$ 4,185 , nőknél $\mathrm{p}=0,085 ; \chi^{2}(5)=9,683$.

Összehasonlítva az útegyütthatókat (3. táblázat), az aszkriptív háttérnek (kor és nem) a kísérő betegségek csoportjára való hatása minden esetben pozitív irányú $\mathrm{A}_{\mathrm{B}} \mathrm{K}_{\mathrm{B}}$ útegyütthatóval jellemezhető; meghatározó az összes modellben a kísérő betegségek dominanciája. A legerősebb hatást kutatásunkban a laparoszkópos esetekben mutatja $(0,38)$. Az aszkriptív háttértényezők számottevő hatása nem mondható el a szövődményekre, az ápolást és mütétet indokló betegségekre sem. Az ellátóintézet $\left(\mathrm{E}_{\mathrm{I}}\right)$ kis hatást igazoló útegyütthatóval jellemez- hető a kísérő $\left(\mathrm{E}_{\mathrm{I}} \mathrm{K}_{\mathrm{B}}\right)$-, ápolást indokló fődiagnózis $\left(\mathrm{E}_{\mathrm{I}} \hat{A}_{\mathrm{B}}\right)$ - és szövődmény $\left(\mathrm{E}_{\mathrm{I}} \mathrm{SZ}\right)$-változókra a TP- és az OCR-csoportban. Az LCR-modellben az $\mathrm{E}_{\mathrm{I}} \mathrm{K}_{\mathrm{B}}(0,1)$ a TP, illetve az OCR modelljéhez képest minimum kétszeres és pozitív előjelú. Szintén az LCR-esetekben az $\mathrm{E}_{\mathrm{T}} \mathrm{SZ}$ $(-0,17)$ útegyüttható negatív irányú, és körülbelül a hatszorosa a többi csoport útegyütthatójának. A kísérő betegségek és a szövődmények csoportjának negatív útegyütthatója $\left(\mathrm{K}_{\mathrm{B}} \mathrm{SZ}:-0,19 ;-0,07\right)$ fordított irányú kapcsolatot jelöl. Az ápolást indokló fódiagnózisok szövődményekkel kapcsolatos hatásánál csak az LCR-csoportnál pozitív irányú (Á $\mathrm{S} Z$ : 0,26$)$, míg a többi esetben (OCR, TP) a szövődményekre negatív ( $\mathrm{A}_{\mathrm{I}} \mathrm{SZ}:-0,3$; $-0,34)$.

$\mathrm{Az}$ aszkriptív háttérblokkon belül a betegek neme az LCR-modellben mutatja a legnagyobb hatást az útegyüttható kialakításában $(-0,21)$. A kor minden modellben meghatározó szerepú az aszkriptív háttér alkotásában, szemben a betegek nemével. A $\mathrm{K}_{\mathrm{B}}$-faktor elemzésekor különválasztottuk az OCR-és a TP-csoport elemzését az LCR modelljének elemzésétől. A magas vérnyomás, az ischaemiás és a hipertenzív szívbetegség, a diabetes mellitus, a hashártya-összenövés csoportjai magas faktorértékként vannak jelen az OCR és a TP strukturális modelljében, ugyanakkor az LCR-elemzésben alacsony, negatív értéket képviselnek. A máj másodlagos daganata negatív előjelü, a legnagyobb hatást az LCRcsoportban mutatja $(-0,34)$. A COPD, az atherosclero- 
LVPLS-modellek regressziós és korrelációs faktorsúlyoknak (eredményei a különböző csoportokban

\begin{tabular}{|c|c|c|c|}
\hline Út- (regressziós) együtthatók & $\mathrm{TP}$ & OCR & LCR \\
\hline Aszkript kísérő $\left(\mathrm{A}_{\mathrm{B}} \mathrm{K}_{\mathrm{B}}\right)$ & 0,24 & 0,24 & 0,38 \\
\hline Aszkript szövődmény $\left(A_{B} S Z\right)$ & $-0,03$ & $-0,03$ & $-0,01$ \\
\hline $\begin{array}{l}\text { Aszkript ápolást indokló fódiagnózis } \\
\left(\mathrm{A}_{\mathrm{B}} \hat{A}_{\mathrm{B}}\right)\end{array}$ & 0,01 & 0,02 & $-0,09$ \\
\hline Intézeti kísérő betegségek $\left(\mathrm{E}_{\mathrm{I}} \mathrm{K}_{\mathrm{B}}\right)$ & $-0,03$ & $-0,04$ & 0,1 \\
\hline Intézeti szövődmény ( $\mathrm{E}_{\mathrm{I}} \mathrm{SZ}$ ) & 0,03 & 0,03 & $-0,17$ \\
\hline Intézeti ápolást indokló $\left(\mathrm{E}_{\mathrm{I}} \hat{\mathrm{A}}_{\mathrm{B}}\right)$ & 0,05 & 0,05 & 0,00 \\
\hline Kísérő szövődmény ( $\left.\mathrm{K}_{\mathrm{B}} \mathrm{SZ}\right)$ & $-0,19$ & $-0,19$ & $-0,07$ \\
\hline Ápolást indokló szövődmény (Á $\mathrm{S} S \mathrm{Z})$ & $-0,34$ & $-0,3$ & 0,26 \\
\hline A blokkokat alkotó faktorsúlyok & $\mathrm{TP}$ & OCR & LCR \\
\hline Életkor & 0,99 & 0,99 & 0,96 \\
\hline Nem & $-0,04$ & $-0,03$ & $-0,21$ \\
\hline Máj másodlagos daganata & $-0,13$ & $-0,14$ & $-0,34$ \\
\hline Magas vérnyomás & 0,37 & 0,37 & $-0,1$ \\
\hline Ischaemiás szív- és érbetegség & 0,46 & 0,49 & $-0,05$ \\
\hline Hashártya-összenövések & $-0,36$ & $-0,34$ & $-0,03$ \\
\hline COPD & $-0,02$ & $-0,03$ & 0,28 \\
\hline Pitvarfibrilláció & 0,4 & 0,4 & 0,46 \\
\hline Diabetes & 0,24 & 0,25 & $-0,1$ \\
\hline Atherosclerosis & 0,25 & 0,24 & 0,52 \\
\hline Krónikus veseelégtelenség & 0,19 & 0,17 & 0,47 \\
\hline Béltályog, bélátfúródás & 0,26 & 0,26 & 0,08 \\
\hline Hashártyagyulladás & 0,71 & 0,71 & $-0,32$ \\
\hline Lágyrész-gyulladás & 0,16 & 0,16 & 0,11 \\
\hline Vérzés, anaemia & $-0,31$ & $-0,28$ & 0,91 \\
\hline Bélelzáródás, volvulus & $-0,03$ & $-0,07$ & $-0,12$ \\
\hline Szepszis & 0,77 & 0,77 & $-0,28$ \\
\hline Végbél - rosszindulatú daganat & 0,37 & 0,36 & $-0,2$ \\
\hline Vastagbél - rosszindulatú daganat & 0,7 & 0,72 & 0,93 \\
\hline Esetszám (műtéti eset) & 4941 & 4562 & 379 \\
\hline $\begin{array}{l}\text { A faktorsúlyok négyzetének } \\
\text { középértékének aránya* }\end{array}$ & 0,1951 & 0,1960 & 0,2017 \\
\hline $\begin{array}{l}\text { A faktorsúlyok négyzetének } \\
\text { középértékének aránya \%-os } \\
\text { formában* }\end{array}$ & 19,51 & 19,60 & 20,17 \\
\hline
\end{tabular}

*A táblázat két utolsó sora a modell illeszkedését méri a manifeszt adatokhoz. Ezek az értékek a modell elfogadását, az adatokhoz való illeszkedésének megfelelőségét bizonyítják.

COPD = idült obstruktív tüdőbetegség; $\mathrm{LCR}$ = laparoszkópos colorectalis reszekció; LVPLS = latens változós útelemzés parciális legkisebb négyzetes becsléssel; OCR = nyitott colorectalis reszekció; $\mathrm{TP}=$ teljes vizsgálati populáció sis, a krónikus veseelégtelenség betegségcsoportoknak szintén az LCR-modellben domináns a jelenléte. A pitvarfibrilláció minden modellnél hasonló, pozitív értékkel van képviselve $(0,4-0,46)$. A szövődmények blokkelemzésekor a kísérô betegségekéihez hasonlóan a TP- és az OCR-modell értékeit az LCR-csoportétól külön elemeztük. A hashártyagyulladás, a szepszis, a béltályog, a bélátfúródás jelentős pozitív értékeket képvisel a TP- és az OCR-modellben, szemben az LCR-modellben tapasztalt TP- és OCR-értékekhez képest kisebb negatív értékekkel (hashártyagyulladás: $-0,32$; szepszis: $-0,28$ ). A vérzés, anaemia kódja a blokkot meghatározóan nagyon erôs pozitív értéket $(0,91)$ képvisel az LCR SZblokkjában, míg a TP- és az OCR-modellnél negatív, és körülbelül harmada az értéke $(-0,31$ és $-0,28)$. A bélelzáródás, volvulus diagnóziscsoport kis hangsúlyú az öszszes modellben. Az ápolást indokló fődiagnózisblokkra jellemző, hogy a vastagbél-daganatos diagnózisnak erős hangsúlyos pozitív hatása van a csoport kialakításában. Az Á $\mathrm{B}$ blokk kapcsán érdekesség, hogy az LCR-modellben negatív előjellel szerepel a végbéldaganatos kód.

\section{Következtetés}

Az eredmények összefüggései előtt szeretnék rámutatni kutatásunk hiányosságaira. Az elemzett adataink központi, nem saját kórházi adatbázisból származnak. Ennek az a hátránya, hogy nem tudjuk esetszinten visszaellenőrizni adatainkat, hagyatkoznunk kellett a jelentési kötelezettségnek eleget tevő intézetek kódolásának megbízhatóságára. Az elemzés egyes összefüggései felvetnek kódolási anomáliákat, amelyek valószínúleg rendszerszintüek; ennek okaira a jelen esetben nem térünk ki. Mindemellett a jelenleg használt HBCs-, beavatkozás- és diagnóziskódok rendszerei évek óta karbantartást igényelnének. Vizsgálatunkban minden, általunk ismert lehetséges eszközt megragadtunk annak eléréséhez, hogy minimalizáljuk az adattorzításokat: beavatkozáskódokra szürve kértük az adatbázis-lekérést, majd a lehetséges szövődmény- és kíséróbetegség-kódcsoportokból a teljes adathalmaz elemzése alapján kódcsoportokat hoztunk létre (1. táblázat); ezeket később a strukturális modell blokkjaiban elemeztük. Minden erőfeszítésünk ellenére számos, anomáliákra gyanús eredményt érzékeltünk, például a kísérő és szövődménybetegségek kapcsolatának negatív iránya vagy a bélelzáródás, volvulus betegségcsoport alulreprezentáltsága a szövődmények között, amelyek oka valószínűsíthetően az, hogy a „tüneti” diagnózis kódolása helyett gyakrabban a teljesen logikus „oki” diagnóziskódot használják a klinikusok.

Az anomáliák mellett számos hasznos és iránymutató összefüggést megfigyeltünk, egyes nemzetközi kutatások eredményeivel összhangban $[26,27]$. Az OCR, TP strukturális modelljével szemben az LPS-modellben több ponton eltérnek az adatok faktorsúlyai és útegyütthatói. Az elemzett útegyütthatók közül az $\mathrm{A}_{\mathrm{B}} \mathrm{K}_{\mathrm{B}}$ nagysága és előjele megerősíti, hogy a kor előrehaladtával do- 
minánsabbak a kísérő betegségek a modellekben. Az LCR-csoport strukturális modelljében az $\mathrm{E}_{\mathrm{I}} \mathrm{K}_{\mathrm{B}}$ alapján pozitív irányú kapcsolat van a kísérő betegségek és a magasabb progresszivitású ellátóhelyeken végzett mütétek között, azaz a multimorbid betegek kerülnek ellátásra a magasabb progresszivitású helyeken, vagy nagyobb hangsúlyt fektetnek itt a kísérő betegségek kódolására. Szintén az LCR-csoportnál az $\mathrm{E}_{\mathrm{I}} \mathrm{SZ}$ esetében a negatív előjel $(-0,17)$ azt jelenti, hogy minél magasabb progreszszivitású helyeken operálják a vastag- és végbéldaganatos betegeket laparoszkópos technikával, annál kevésbé domináns a szövődmények kódolása, azaz vagy kevesebb a szövődmény, vagy más kódolási módszert alkalmaznak szisztematikusan, mint a progresszivitás alacsonyabb szintjein. Elvárásunk lenne a kísérő betegségek erős pozitív kapcsolata a szövődménykódokkal $\left(\mathrm{K}_{\mathrm{B}} \mathrm{SZ}\right)$, azaz több kísérő betegség esetén a szövődmények nagyobb hangsúllyal szerepeljenek modellünkben. A kérdést azonban nem lehet ennyire leegyszerüsítve vizsgálni; a $\mathrm{K}_{\mathrm{B}} \mathrm{SZ}$ útegyüttható negativitásának magyarázata többek között az, hogy a vizsgált szövődményeket nem lehet egyértelmúen ok-okozati összefüggésbe állítani, illetve csak részben van kapcsolat a modellbe bevont kísérő betegségekkel. Befolyásolja eredményünket az is, hogy a magasabb progresszivitású intézetekben nagyobb a kísérő betegség hangsúlya, de ugyanitt a szövődmény nem domináns olyan mértékben, mint a progresszivitás alacsonyabb szintjén lévő ellátóknál, ahol viszont pont fordított a helyzet. A kérdés hátterét színesítik a korábban említett vélt kódolási anomáliák. Az Á SZ értékéről elmondható, hogy az LCR-csoportban egyértelmú és azonos irányú kapcsolatot jelent a vizsgált fódiagnózisok és szövődmények mintázata között, míg az OCR és a TP esetében erősebb negatív útegyüttható oka abban rejlik, hogy a vastag- és végbéldaganatos betegségek mint mütéti ok markánsan ellensúlyozzák a szövődmények lehetséges hatását a modellben. A jelen kutatásban nem vizsgált, ápolást indokló fődiagnózisok bevonása ezt a hatást kiegyensúlyozná. A blokkokat alkotó változók hatásai között is fellelhetók fontos és érdekes megfigyelések, ilyen a nemek szerepe és hangsúlya az $\mathrm{A}_{\mathrm{B}}$-faktor kialakításában. Az LCR-csoportban a férfinem hangsúlya a többi modellhez képest erőteljesebb, az életkor, az aszkriptív változó egyértelmű meghatározó szerepe mellett. A kísérôbetegség-faktorsúlyok blokkon belüli vizsgálatakor az OCR- és a TP-csoport értékei között párhuzamosság van, eredményeik teljesen eltérnek az LCR-csoport hasonló faktorsúlyaitól. Az eredmények alapján a TP- és az OCR-csoportra jellemzően azon belgyógyászati kórképek mutatnak nagy befolyást a faktor kialakításában, amelyek egyébként a magyar populációra jellemző nagy esetszámú betegségcsoportokat jelölnek. Az LCR-csoport ezzel szemben heterogén képet nyújt: a krónikus veseelégtelenség, a pitvarfibrilláció, az atherosclerosis és az asztma betegségcsoportok faktorsúlyainak vannak befolyásoló szerepeik a faktorképzésben. Az OCR-, a TPés az LCR-modell-értékek eltérésének okai között rész- ben a betegek mütéti szelekcióját feltételezzük az ápolást indokló betegség súlyossága, a kísérő betegségek összetétele alapján, amelynek vizsgálatára további célzott kutatások lennének szükségesek. A szövődmények közül az OCR- és a TP-csoportra jellemző a szepszisnek, a hashártyagyulladásnak és a béltályognak a faktort meghatározó dominanciája, szemben az LCR-modellben a vérzés, anaemia hangsúlyával, ami a mütéttechnikák és az egyes szövődmények közötti egyedi kapcsolatot jelenti, ahogy azt a nemzetközi irodalomban is több kutatás kimutatta $[27,28]$ az alapbetegség miatti szövődmények mellett. A kódolt adatok igazolása és az anomáliák kiszűrése céljából további kutatás keretein belül a magyar gyakorlatban lehetséges élettani, kódolási és mútéttechnikai jellegü okokat lenne érdemes feltérképezni.

Anyagi érdekeltség: A kézirat elkészítése és a kapcsolódó kutatómunka anyagi támogatásban nem részesült.

A szerző a cikk végleges változatát elolvasta és jóváhagyta.

Érdekeltségek: A szerzőnek nincs pénzügyi vagy személyes érdekeltsége a cikk összeállításával kapcsolatban.

\section{Köszönetnyilvánítás}

A szerző ezúton is köszönetét fejezi ki $d r$. Füstös László egyetemi tanárnak a statisztikai számítások elkészítésében nyújtott segítségéért. Professzor úr irányítása, áldozatos és önzetlen segítsége nélkül azok nem valósulhattak volna meg.

\section{Irodalom}

[1] Delaney CP, Marcello PW, Sonoda T, et al. Gastrointestinal recovery after laparoscopic colectomy: results of a prospective, observational, multicenter study. Surg Endosc. 2010; 24: 653-661

[2] Raymond TM, Kumar S, Dastur JK, et al. Case controlled study of the hospital stay and return to full activity following laparoscopic and open colorectal surgery before and after the introduction of an enhanced recovery programme. Colorectal Dis. 2010; 12: 1001-1006.

[3] Guillou PJ, Quirke P, Thorpe H, et al. Short-term endpoints of conventional versus laparoscopic assisted surgery in patients with colorectal cancer (MRC CLASICC trial): multicentre, randomized controlled trial. Lancet 2005; 365: 1718-1726.

[4] Keller DS, Delaney CP, Hashemi L, et al. A national evaluation of clinical and economic outcomes in open versus laparoscopic colorectal surgery. Surg Endosc. 2016; 30: 4220-4228.

[5] Lian L, Kalady M, Geisler D, et al. Laparoscopic colectomy is safe and leads to a significantly shorter hospital stay for octogenarians. Surg Endosc. 2010; 24: 2039-2043.

[6] Stefanou AJ, Reickert CA, Velanovich V, et al. Laparoscopic colectomy significantly decreases length of stay compared with open operation. Surg Endosc. 2012; 26: 144-148.

[7] Chen K, Cao G, Chen B, al. Laparoscopic versus open surgery for rectal cancer: a meta-analysis of classic randomized controlled trials and high-quality Nonrandomized Studies in the last $\mathbf{5}$ years. Int J Surg. 2017; 39: 1-10. 
[8] Lacy AM, Garcia-Valdecasas JC, Delgado S, et al. Laparoscopyassisted colectomy versus open colectomy for treatment of nonmetastatic colon cancer: a randomized trial. Lancet 2002; 359: 2224-2229.

[9] Janson M, Lindholm E, Anderberg B, et al. Randomized trial of health-related quality of life after open and laparoscopic surgery for colon cancer. Surg Endosc. 2007; 21: 747-753.

[10] The Colon Cancer Laparoscopic or Open Resection Study Group. Survival after laparoscopic surgery versus open surgery for colon cancer: long-term outcome of a randomised clinical trial. Lancet Oncol. 2009; 10: 44-52.

[11] Janurova K, Martinek L. Assessment of mortality risk for patients undergoing colorectal surgery using regression modeling. In: Bris R, Majernik J, Pancerz K, et al. (eds.) Applications of computational intelligence in biomedical technology. Springer-Verlag, Berlin, 2016; pp. 47-66.

[12] Sokolovic E, Buchmann P, Schlomowitsch F, et al. Comparison of resource utilization and long-term quality-of-life outcomes between laparoscopic and conventional colorectal surgery. Surg Endosc. 2004; 18: 1663-1667.

[13] Laurent C, Leblanc F, Bretagnol F, et al. Long-term wound advantages of the laparoscopic approach in rectal cancer. Br J Surg. 2008; 95: 903-908

[14] Delaney CP, Chang E, Senagore AJ, et al. Clinical outcomes and resource utilization associated with laparoscopic and open colectomy using a large national database. Ann Surg. 2008; 247: 819-824.

[15] Veldkamp R, Kuhry E, Hop WC, et al. Laparoscopic surgery versus open surgery for colon cancer: short-term outcomes of a randomized trial. Lancet Oncol. 2005; 6: 477-484.

[16] Papp G, Bánky B, Lakatos M, et al. New perspectives in rectal cancer surgery: transanal total mesorectal excision. Initial experiences. [Új távlatok a végbélrák sebészetében: Transanalis teljes mesorectum excisio. Kezdeti eredményeink.] Orv Hetil. 2018; 159: 16-22. [Hungarian]

[17] Krenyácz É, Benedek Zs. Costs and benefits of the laparoscopic colorectal operations - a micro and mezzo level analysis. [A laparoszkópos colorectalis mútétek haszna és költségei - mikro és mezzo szintû́ elemzés.] IME 2012; 11: 20-25. [Hungarian]

[18] Benedek Zs, Krenyácz É. Economical aspects of laparoscopic colorectal surgery in inpatient care. [A laparoszkópos colorectalis sebészet gazdasági vonatkozásai a fekvőbeteg-ellátás szintjén.] LAM 2013; 23: 125-133. [Hungarian]
[19] Delaney CP, Kiran RP, Senagore AJ, et al. Case-matched comparison of clinical and financial outcome after laparoscopic or open colorectal surgery. Ann Surg. 2003; 238: 67-72.

[20] Miskovic D, Ni M, Wyles SM, et al. Learning curve and case selection in laparoscopic colorectal surgery: systematic review and international multicenter analysis of 4852 cases. Dis Colon Rectum 2012; 55: 1300-1310.

[21] Prakash K, Kamalesh NP, Pramil K, et al. Does case selection and outcome following laparoscopic colorectal resection change after initial learning curve? Analysis of 235 consecutive elective laparoscopic colorectal resections. J Minim Access Surg. 2013; 9: 99103.

[22] Waters JA, Chihara R, Moreno J, et al. Laparoscopic colectomy: does the learning curve extend beyond colorectal surgery fellowship? JSLS 2010; 14: 325-331.

[23] Füstös L, Tárnok O. Structural equation modeling: Second generational statistical analysis methods. [Strukturális egyenletek modellje: Másodgenerációs statisztikai módszerek.] TEAM Társadalmi Elemzések Alkalmazott Múhelye, Módszertani füzetek, 2017. ISSN 2062-2473. [Hungarian]

[24] Jermendy Gy, Kempler P, Abonyi-Tóth Zs, et al. Changes in features of diabetes care in Hungary in the period of years 20012014. Aims and methods of the database analysis of the National Health Insurance Fund. [A cukorbeteg-ellátás mutatóinak alakulása Magyarországon 2001-2014 között. Az Országos Egészségbiztosítási Pénztár adatbázis-elemzésének célja és módszertana.] Orv Hetil. 2016; 157: 1259-1265. [Hungarian]

[25] Lohmöller JB. Latent variable path modeling with partial least squares. Physica-Verlag, Heidelberg, 1989.

[26] Ciorogar G, Bartos A, Bartos D, et al. Rectal cancer: factors predicting short outcomes after radical anterior resection. Ann Ital Chir. 2017; 88: 505-513.

[27] Howard DP, Datta G, Cunnick G, et al. Surgical site infection rate is lower in laparoscopic than open colorectal surgery. Colorectal Dis. 2010; 12: 423-427.

[28] Drosdeck J, Harzman A, Suzo A, et al. Multivariate analysis of risk factors for surgical site infection after laparoscopic colorectal surgery. Surg Endosc. 2013; 27: 4574-4580.

(Benedek Zsófia dr.,

Budapest, Felső Svábhegyi út 11. A fszt. 4., 1125 e-mail cím: benedek.zsofi0411@gmail.com)

\section{"Nulla dies abeat, quin linea ducta supersit." (Ne teljen úgy el nap, hogy nem tettél valamit.)}

A cikk a Creative Commons Attribution 4.0 International License (https://creativecommons.org/licenses/by/4.0/) feltételei szerint publikált Open Access közlemény, melynek szellemében a cikk bármilyen médiumban szabadon felhasználható, megosztható és újraközölhető, feltéve, hogy az eredeti szerző és a közlés helye, illetve a CC License linkje és az esetlegesen végrehajtott módosítások feltüntetésre kerülnek. (SID_1) 